\title{
Questioning the Weber Thesis: Capitalist Ethics and the Hebrew Bible?
}

\author{
Sigmund Wagner-Tsukamoto \\ University of Leicester, Leicester, UK \\ Email: sawt444@aol.com
}

Received September $2^{\text {nd }}, 2011$; revised October $16^{\text {th }}, 2011$; accepted November 22 $2^{\text {nd }}, 2011$

\begin{abstract}
Weber's thesis proposed that it was ascetic Protestantism which supported the emergence of modern capitalism in 17th and 18th century Europe, and that this was a completely new and unique phenomenon in the history of mankind up to that point in time. This paper casts doubt on the Weber thesis by examining findings from an economic reconstruction of the Hebrew Bible, and proposing that modern capitalism the way Weber understood it is already visible in the ancient religious text of the "Hebrew Bible". By means of institutional economic reconstruction, I show that the Hebrew Bible and particularly the stories involving Jacob and Joseph reveal a conceptual structure that can be compared with ideas of modern constitutional and institutional economics. Through this reconstruction, I find myself in agreement with one of Weber's early but largely forgotten adversaries, Werner Sombart, who suggested, in a behavioral tradition, that other religions, and more specifically Jewish thought, contributed to the emergence of modern capitalism long before the advent of Protestantism.
\end{abstract}

Keywords: Weber Thesis; Sombart Thesis; Capitalist Ethics of the Hebrew Bible; Capitalist Ethics of Religion

\section{Introduction}

Max Weber had his critics early on when he proposed the thesis that it was primarily ascetic Protestantism which supported the emergence of capitalism in the Western World in the 17th and 18th century, because, so Weber claimed, Protestantism gave rise to a new spiritual attitude towards the making of profit. Werner Sombart was critical of Weber's position, and claimed that there were other historic developments which had seen religion contribute to a capitalist ethos and a "calling for making money”, as Weber put it. Sombart $(1911,1913)$ here especially focused on the entrepreneurial success of Jewish businesses and their role in the economy. However, mainstream theology, sociology, or economic sociology have largely forgotten and ignored Sombart's critique of Weber, as Grundmann and Stehr (2001), for example, noted with regard to classical sociology.

In the present paper, I question Weber's thesis through an institutional economic reconstruction of some of the key stories of the Hebrew Bible, such as the Genesis stories involving Jacob and Joseph. Basic concepts of institutional economic reconstruction of texts of the Hebrew Bible have been set out in detail elsewhere (Wagner-Tsukamoto, 2009a, 2009b, 2010, 2011, 2012; see also Wagner-Tsukamoto, 2007). These stories belong to the earliest, best-known and most fundamental parts of the Hebrew Bible and are some 4000 - 5000 years old. My critique proceeded in two steps.

First, by means of textual, economic analysis-this methodological approach was outlined in detail by Wagner-Tsukamoto (2009a, 2009b), I argue that the Hebrew Bible reflects a deeply economic and capitalist ethos the way Weber understood it. Capitalist ethics can in this respect be attributed to some of the key stories of the Hebrew Bible. In this way, I closed a gap in Sombart's critique of Weber: Sombart (1911: pp. 293-294) specifically asked whether it could be shown that Judaism had influenced ascetic Protestantism. However, he intentionally left such clarifications to experts in Church history - who never really picked up this research question (Lehmann, 1993: p. 200). My economic reconstruction of stories of the Hebrew Bible addressed this forgotten question. I conceptually drew on ideas of constitutional and institutional economics and the discussion of private contracting and societal contracting. Subsequently I explained these ideas when undertaking my economic reconstruction of the Hebrew Bible. As noted above, these ideas were originally introduced by Wagner-Tsukamoto (2001, 2007, 2008a, 2009a, 2009b, 2010, 2011, 2012).

Thus, by means of institutional economic reconstruction I radicalized the Weber/Sombart dispute, siding with Sombart. I did so by showing that key concepts of modern capitalism the way Weber understood them are already clearly visible in the Hebrew Bible hence implying that modern capitalism, as suspected by Sombart, already existed in ancient times. A key discovery is that as Weber suggested, capitalist institutions as we know them do have religious roots, but are-contrary to Weber-not Protestant but in fact Jewish and date much further back than Weber anticipated, at least to biblical times, as the present paper reveals.

The key point I am making in challenging the Weber thesis is that modern capitalism predates Weber's suggestions. I propose that Judaism gave rise to modern capitalism in ancient times, i.e. when the Hebrew Bible was written. I basically agree with Sombart on this issue, showing that it was essential features from Judaism, which deeply reflect on the Hebrew Bible, which in my reading, gave rise to modern capitalism ("modern" as Weber understood it) already in ancient times.

In a second step, I extend my textual critique of Weber's the- 
sis in actual, historical perspective. This gives new and additional substance and relevance to Sombart's criticism of Weber. Sombart (1913) clarified early on how Judaism contributed to a capitalist ethos and how the geographic shift in Jewish economic involvement across Europe in the 17th and 18th century could account for the changing economic success of various countries. I make the historical point that whenever institutional barriers were lowered or removed in any country that restricted Jews from engaging in economic activity, Jews subsequently contributed over-proportionally to the economic development and economic performance of that country.

\section{Weber's Thesis and Sombart's Thesis}

Weber's and Sombart's works on modern capitalism share much common ground between them. Sombart (1902) first published ideas on how he thought modern capitalism had been shaped, amongst other factors by Jewish involvement. Weber's treatise on the Protestant ethics and modern capitalism then seemed to be, at least in part, a counter-point to Sombart, advancing as an alternative thesis the idea that it was ascetic Protestants who developed modern capitalism in Europe rather than the Jews. This debate took a step further when Sombart subsequently published his specialized study on the Jews and modern capitalism $(1911,1913)$, criticizing Weber (e.g. Sombart, 1913: pp. 191-192, 248), to which Weber replied in later editions of his study (Lehmann, 1993: pp. 196-198).

The Weber thesis states that ascetic Protestantism, as it developed in 17th and 18th century-Europe, supported the emergence of modern capitalism as an economic system because ascetic Protestantism was accompanied by a new spiritual attitude towards profit-making (see Lehmann, 1993; MacKinnon, 1993; Nipperdey, 1993). In this respect, Weber made out a new worldview (Weltanschauung) for Protestantism—a deep-rooted devotion to the calling of making money (Weber, 2001: p. 51, 72). He claimed such an economic devotion and conduct of life (Lebensführung) was absent from earlier economic activity in the history of mankind, even amongst Jewish civilizations.

Weber characterized modern capitalism alongside four criteria (Weber, 1976: pp. 21-22, 51-52, 72; Weber, 2001: pp. 29-31, 111; see also Wagner-Tsukamoto, 2009a, Section 7.6): (a) the rational, industrial organization of free labor; (b) a rational book-keeping system; (c) the separation of corporate activity and corporate property from the household and private property; and (d) economic activity that reflected the spirit of capitalism. Weber endorsed in this respect the strong claim that businesses that showed these four features were a peculiar modern capitalist phenomenon, which had only arisen with the coming of ascetic Protestantism. Regarding the spirit of capitalism, Weber drew on one concrete example of historic economic activity of the Huguenots, to illustrate in more detail what the meaning of the spirit of modern capitalism was, by expanding further criteria (d):

"The [Huguenot] entrepreneur [in 17th and 18th century Europe] emerged with an utterly clear conscience, filled with the consciousness 1) that Providence was showing him the path to profit, so that he might tread it to God's glory; 2) that God was visibly blessing him in the increase of his profit and possessions; 3 ) that he could measure his worth, not only before men, but before God, above all the success in his calling, provided this was achieved by legal means; and 4) that God had a pur- pose in selecting precisely him for economic advancement and had equipped him with means to achieve it (Weber, 2002: p. 312; see also Lehmann, 2005: p. 19).”

I will refer to these four criteria subsequently as the Huguenot criteria, in order to differentiate them from Weber's other four criteria for the demarcation of modern capitalism.

Weber was certainly aware that Jewish involvement in economic activity had played a key role in the evolution of modern capitalism from the 17th and 18th century onwards but he questioned whether this reflected involvement in rational industrial organization, especially in factory-type organization (Weber, 1965: p. 249; see also Grundmann \& Stehr, 2001: pp. 266-267). He characterized Jews as adventurer capitalists but not modern capitalists and he characterized their religious belief system as traditionalist and pre-modern (Weber, 1924: p. 307, 1965: p. 246, 2001: p. 130, 244-245). My analysis later challenges, through institutional economic reconstruction, this thesis by unearthing within the text of the "Hebrew Bible" a very modern, economic ethos which to a considerable degree lives up to all four of Weber's criteria, including the Huguenot criteria. I therefore argue that modern capitalism the way Weber understood it is already visible in the Hebrew Bible-and that this had a deep, real-world impact on the Jewish businessperson by being rooted in the Jewish religion, culture, and history. Implications of this finding could then be explored further regarding the actual emergence of "modern" capitalism as far back as in ancient times (this, however, is beyond the scope of the present paper).

Sombart's key criticism of Weber was that other religions and here especially Judaism contributed to the emergence of capitalism much earlier than Weber envisaged (Sombart thesis). Sombart (1913: p. 21) specifically put forward the two theses that Jews:

(1) influenced the outward form of modern capitalism in (1a) giving economic relations the international aspect they bear today; (1b) in helping the modern state, that framework of capitalism, to become what it is; and (1c) in giving the capitalist organization its peculiar features; and (2) gave expression to the inward spirit of modern capitalism, seizing upon the essential idea of capitalism and carrying it to its fullest development (quotations abridged, numbers added).

There are considerable similarities but also significant differences between Weber's and Sombart's criteria for outlining modern capitalism. Weber's criteria (a), (b) and (c) explained in detail what Sombart, at least at this point, had only summarized through the more general statement of (1c). Weber's criteria (d) and Sombart's criteria (2) seem to largely overlap. For instance, Sombart suggested that the spirit of capitalism is a peculiar spirit of enterprise, namely “... the making of profit as an end which dominates the whole [economic] system ... Economic activity, which is originally purely a means to an end, becomes an absolute end in itself, the expression of a religion” (Parsons, 1928-1929: pp. 649-650). But Weber seemed to specify in more detail, for instance through the Huguenot criteria, what his idea of the spirit of capitalism was. Both Weber and Sombart agreed that this spirit is enforced on the modern entrepreneur by the capitalist system (Parsons, 1928-1929: p. 35; see also Wagner-Tsukamoto, 2005: p. 79).

However, Sombart went further and included some interesting features in his outline of modern capitalism which Weber seemingly omitted. Sombart's criterion (1a) touches on issues 
of globalizing business, and (1b) on the institutional and constitutional enactment of capitalism through certain rule structures. In these latter respects Sombart's outline is more sophisticated, and future research could make projections between Sombart's early outline of modern capitalism and more recent contemporary developments in our understanding of the global and institutional/constitutional nature of capitalism. For the purposes of this paper, my focus was on Weber's criteria for analyzing modern capitalism in order to make my point that Jews and Judaism played a more significant and earlier role in driving modern capitalism ("modern" in Weber's reading) than Weber had envisaged.

Sombart's studies may be biased in certain respects, possibly even reflecting anti-Semitic attitudes since he made some points by attributing certain psychological and sociological features to the Jewish mind (Sombart, 1911; see also Grundmann \& Stehr, 2001: pp. 269-270). Sombart had his critics in this respect (e.g. Landheer, 1951; Swatos \& Kivisto, 2005: p. 115). For instance, he proposed that the Jews “... share in the genesis of capitalism ... follows from, among other things, their racial disposition” (Sombart, 1902: p. 390). In this respect, I cannot agree with Sombart. Rather, I suggest that Judaism could anticipate and perpetrate a capitalist ethos as Weber identified it later for ascetic Protestantism because of learned, religious, cultural and historical experience in relation to the text "Hebrew Bible". Interestingly, Sombart (1913: chap. 11, 1915: pp. 232-235) also touched on this issue to a considerable degree, but he focused mainly on Talmudic texts, as did Mosse (1987: p. 28), to outline a modern spirit of Judaism. Weber (1965: p. $246,2001)$ generally discounted Judaism in this respect as traditionalistic and pre-modern (focusing, like Sombart and Mosse, on post-exilic literature, such as the Mosaic laws and the Talmud). I argue, by focusing on Genesis, which is one of the earliest, most fundamental and pre-exodus parts ${ }^{1}$ of the Hebrew Bible, that Judaism very significantly contributed to the development of modern capitalism.

In my view, Sombart could have considerably strengthened his case by actually examining the oldest, pre-exodus parts of the Hebrew Bible for a capitalist ethos. These parts reflect the religious, cultural backbone of Judaism, especially its patriarchal textual history, and hence are likely to have had a deep impact on actual learned religious and culturally influenced behavior, as it is grounded in Judaism. The present paper departs in this respect from Sombart. Also, unlike Sombart, I examined the Hebrew Bible for Weber's criteria and thus contested Weber on his own ground (whereas Sombart had his "own" criteria, and therefore one could argue these were incompatible, at least to some degree, with those of Weber). In this way, the present paper provides novel and different support

\footnotetext{
${ }^{1}$ I justify my focus on pre-exodus rather than post-exilic and post-exodus texts of the Hebrew Bible, which allows for such a fundamental questioning of the Weber thesis, through a climax thesis and a hero thesis which I associate with the story of Joseph of Genesis and the way storytelling is set out in Genesis (Wagner-Tsukamoto, 2009a). In contrast, I relate, for various reasons, a decline thesis to storytelling after the book of Genesis and a nonhero thesis to Moses' involvement in leading Israel out of Egypt. In this respect, I disassociate from possibly legalistic traditionalism, which Judaism may have leaned on after the exile, although even for some of the post-exilic stories traditionalism can be questioned, e.g. for the Solomon story. These climax thesis and decline thesis resolve through economic reconstruction at least some of the "idiosyncrasies" to which Weber (1965: p. 250) refers and which, if unresolved, can explain the misleading characterization of Judaism as traditionalistic and pre-modern, as done by Weber in considerable degrees.
}

to Sombart's early critique of Weber. I outline that stories of the Hebrew Bible in themselves reflect a deeply capitalist ethos and modern, capitalist ethics ("modern" the way Weber understood it) and that this subsequently contributed, largely in a religious- and cultural-pedagogic manner, to the emergence of the successful modern business from "earliest times” onwards, and with it the businessperson who culturally embraced Judaism (see also Sombart, 1913: p. 193, 197). Other religious businesspersons should not be overlooked either who took inspiration from the Hebrew Bible, such as Muslims and Christians, and possibly more so Protestants rather than non-Protestants. The latter issue gives rise to another interesting thesis, also touched upon by Sombart (see above) and discussed in more detail below.

\section{Implications of an Institutional Economic Reconstruction of the Hebrew Bible for the Weber Thesis}

In the following, I looked at some of the key stories of the Hebrew Bible which in my view portray a deeply modern, economic ethos. The analysis is textual at this point, meaning I only looked at an economic reconstruction of stories and the storyline as it is laid out in the text "Hebrew Bible". However, I have cut short this analysis in the present paper since this has already been extensively done elsewhere (see Wagner-Tsukamoto, 2001, 2008a, 2009a, 2009b, 2010, 2011, 2012). Instead, the key purpose of this paper is to project an economic reconstruction of stories of the Hebrew Bible to a critique of the Weber thesis. The stories I subsequently focused on were the Genesis stories involving Jacob and Joseph. A key thesis here is that these figures reflect modern capitalists and the spirit of capitalism as Weber had attributed it only to "capitalists" of 17 th and 18th century-Europe who followed ascetic Protestantism. Then I traced into the story of Jacob and the story of Joseph ideas of modern capitalism as reflected by the aforementioned four criteria of Weber, and also projected Weber's Huguenot criteria to the story of Jacob and the story of Joseph.

\section{Weber's Criteria for Modern Capitalism and the Story of Jacob}

In the story of Jacob there are various sub-stories which reflect economic capital exchange: Jacob's extortion of Esau's birthright for a little bit of food; Jacob's deceit of his father Isaac regarding the right to be blessed as first-born-a right which the Hebrew Bible largely economically interpreted (Armstrong, 1996: p. 78; Wagner-Tsukamoto, 2008: Section 3.2); Jacob's various questionable marriage and farming interactions with his employer Laban; and ultimately Jacob's fight with God which Jacob won and in which Jacob "extorted" a blessing from God (Genesis, 32: verses 24-28; ${ }^{2}$ Wagner-Tsukamoto, 2009a, Section 3.2). The important question is whether we can identify Weber's four criteria for demarcating modern capitalism in these stories.

For all sub-stories herein described we do not find a free organization of labor or the entering of market transactions without

\footnotetext{
${ }^{2}$ All Scripture references relate to the HOLY BIBLE, NEW INTERNATIONAL VERSION ${ }^{\circledR}$. NIV ${ }^{\circledR}$. Copyright ${ }^{\complement} 1973,1978,1984$ by International Bible Society ${ }^{\odot}$. All rights reserved worldwide. Used by permission of Hodder \& Stoughton Publishers, a member of the Hachette Livre UK Group. All rights reserved. "NIV" is a registered trademark of International Bible Society. UK trademark number 1448790.
} 
forced exploitation. Even for the Jacob-Laban interactions force played a considerable role since Jacob was made to work for Laban by Isaac. And yet another aspect of the rational organization of labor can be observed for the Jacob-Laban interactions, namely the emergence of delegation in a hierarchical system of labor and the type of control problems this yielded (see below). However, in the final outcome of the stories of Jacob we can observe free market transactions, namely when Jacob buys land to set up his nation (Genesis, 33: verses 19-20). This was in stark contrast to the way his forefathers Noah, Abraham, or Isaac had acquired land for their nations in a non- economic manner, being given land by God as a reward for their faithfulness.

Regarding Weber's second criteria, a rational bookkeeping system cannot be observed for the interactions involving Jacob with Esau, Isaac, God or the purchase of his land. This is due to the singular nature of these interactions being one-off transactions. Compare this with the Jacob-Laban interactions where the existence of some kind of monitoring system of farming capital is apparent since Laban over time noticed a decrease in his livestock and an increase in Jacob's livestock. As part of Jacob's remuneration by Laban, Jacob was allowed to keep all newly born speckled goats and sheep. However, since Jacob was the shepherd of Laban's herds he could influence through clever breeding tactics the number of speckled goats and sheep that were born. A problem of unregulated delegation and incomplete contracting in a hierarchical relationship existed here. The existence of some kind of bookkeeping system becomes apparent as Laban was able to analyze and uncover this breeding problem. Also, when looking at Jacob's interactions in sum and the way he accumulated wealth from his interactions with Esau, Isaac, Laban and ultimately God allows for the conclusion that Jacob had sufficient skills to save and build up capital, which he finally used to buy land for his nation. Entrepreneurial bookkeeping regarding wealth accumulation on one's own behalf is implied.

Weber's third criteria, the separation of corporate property and activity from the household and private property, can again largely be detected within the Jacob-Laban interactions, which revealed an employment relationship and hereto related delegation and control problems. When Laban employed Jacob to look after his herds, the problem of how to successfully control delegation in the context of separated "corporate" and "private" property develops, especially since Jacob's remuneration plan involved the property he was meant to take care of. At least to some degree we can observe here a feature of modern capitalism at work.

Weber emphasized that modern capitalism was characterized by a true spirit, devotion or calling to making money rather than irrational speculation or forced exploitation by a third party (Kaelber, 2005: pp. 143-144). Unquestionably Jacob was devoted to "making money" but did this reflect godly inspiration and a true spirit? At first glance, Jacob does not seem to live up to this criterion. Many analysts of the stories of Jacob have variously described him as antagonistic, cheating, deceitful and extortive (e.g. Rad, 1963: p. 273, 276, 304; Graves \& Patai, 1964: p. 198, 200; Davidson, 1979: p. 140; Plaut, 1981: p. 190; Westermann, 1986: pp. 431-444; see also Weber, 1952). An institutional economics would in this respect characterize Jacob as opportunistic and predatory in the way Buchanan (1975), North and Thomas (1973) or Williamson (1985) introduced these terms into economic analysis for examining economic man-behavior (Wagner-Tsukamoto, 2009a: Sections 3.2 \& 3.3). Still, this is not the end of the story, as Weber (1952: p. 50) im- plies when reviewing the story of Jacob.

Ultimately, Jacob was tamed through a rather complex web of tit-for-tat interactions wherein he pays back his counterparts, whom he previously had unfairly negotiated with. For instance, a peace treaty was negotiated with Esau and a monetary payment was then made to him (Genesis, 32: verses 13-15, 33: verses 10-11); or a new herding arrangement was set up with Laban once loopholes of incomplete contracting of the previous arrangement had become apparent. Axelrod (1984) may speak of the evolution of cooperation by means of an evolutionary, tit-fortat economics. I would further add that tit-for-tat came with a larger purpose, namely to ultimately negotiate fairer contracts among involved parties. The emergence of a constitutional contract is visible in the tradition of Buchanan's (1975) constitutional economics, specifically one that sees agents bound by more balanced and more freely negotiated social order.

Weber's distinction of booty/robber capitalism from rational capitalism (Kaelber, 2005: pp. 141-142) is very interesting in this connection. Booty capitalism he explained as being profitmaking that draws on unequal or forced capital exchange between agents; rational capitalism, on the other hand, refers to the free engagement of agents into market transactions that aim at profit-making through entrepreneurship and innovation (and Weber equated rational capitalism with modern capitalism, as he saw it emerge in 17th and 18th century Europe; see Kaelber 2005: p. 143). Such a shift from booty/robber capitalism to modern capitalism can be observed in the story of Jacob when Jacob was finally tamed through various tit-for-tat interactions and new contractual arrangements were set up that ensured fairer market transactions. The spirit of modern capitalism is thus visible in the story of Jacob once conflicts were renegotiated in economic terms and this seems to be in line with expectations on "Jewish ethos".

Weber's Huguenot criteria were listed above. When viewed as a process with a goal and when looking at the outcomes of the stories of Jacob, the Huguenot criteria appear to be fulfilled. Only when looking at individual sub-stories in isolation can the criteria be questioned. Regarding criteria (1), in the end Jacob traded wealth to God's glory when he finally set up an altar to honor God on the land he had acquired for his nation. At least then, Jacob respected ethical limitations-a phenomenon which Weber (2001: p. 22) associated with modern capitalists. Regarding criteria (2), God actually blessed Jacob as a result of their nightly fight (and as noted above, the blessing is interpreted by the Hebrew Bible in a rather economic manner). Regarding criteria (3), Jacob strived to be blessed by God which implies that he wanted to measure his worth before God; I discussed the issue of "legal" means above when outlining that Jacob's at times rather dubious interactions were ultimately corrected through various repayment schemes, which finally ensured legality and morality. Regarding criteria (4), God selected Jacob by making him a biblical patriarch-through blessing him-and by re-naming him as "Israel". The latter reflects a very special reward and elevation which was not granted to any of the other patriarchs. So, an examination of the Huguenot criteria also underlines that a devotion and calling to making money in relation to godly involvement is apparent in the stories of Jacob-but in a Jewish understanding and not necessarily ascetic one, as Weber may expect.

\section{Weber's Criteria for Modern Capitalism and the Story of Joseph}

The story of Joseph is one of the longest integrated narratives 
in the Hebrew Bible. Again there are various sub-stories but the key story I focused on in the following was Joseph's involvement in the running of Egypt's industrial hierarchies. Ultimately, Joseph occupied a senior position in Egypt, reporting only to the pharaoh as his superior.

Weber's first criterion for the demarcation of modern capitalism refers to the rational industrial organization of free labor. This criterion is very much apparent in the story of Joseph. Although Joseph entered Egypt's industrial hierarchies as a slave (having been sold by his brothers to slave traders), he was quickly able to relinquish this role because of his managerial and economic wits. His career path in Egypt amply reflects this. He started as a household slave, but then was promoted to household administrator, then administrator of farming projects, then head of the security department of Egypt, then head of the prison department to finally become the "lord and ruler of all Egypt" who only answered to the pharaoh (Genesis, 41: verses 40-45, 42: verse 8, 45: verses 8-9, 26; see also Gordon, 1989: p. 7).

The rational, industrial organization of labor in managerial hierarchies is visible. Also, other members in this industrial hierarchy were free to enter or leave; a key example here being the voluntary relocation of the Israelites to Egypt once their homeland encountered famines and draughts. Thus, the idea of slavery has to be discounted for the story of Joseph despite the fact that Greek and Latin translations of the Hebrew Bible contain the phrase that Joseph made "slaves of the people". Weber (1952: p. 50) wrongly states this issue, too. In the older and original text of the Hebrew Bible, the Masoretic text, this phrase reads differently, namely as Joseph "moving the people to the city” (Rad, 1963: p. 405; Davidson, 1979: pp. 287-288; Schmidt, 1984: p. 36). As discussed below, the concept of private property was very much upheld in the story of Joseph.

Regarding criterion two, the existence of a rational bookkeeping system, this is most apparent in the story of Joseph when it comes to the administration of Joseph's barter tax system for crop. Joseph introduced a 20 per cent barter tax on crop production in order to buffer Egypt against cycles of economic downturn. The administration of this tax, the related storage of crop and the redistribution of tax into the economy in a downturn cycle clearly required a sophisticated bookkeeping system. We can even suggest that Joseph acted here as a "private businessman" in the sense that Weber would have recognized when introducing this tax, namely as the senior manager in charge of running a state enterprise (large parts of the Egyptian economy).

Criterion three relates to the separation of corporate activity and corporate property from the household and private property. It is convincingly fulfilled in the story of Joseph. For example, the 20 percent barter tax already reflects this (80 percent of crop yield remaining private property while 20 percent was to be handed to the state). More directly it is visible when Joseph transfers private production property into the hands of the entrepreneur "state". This property transfer was economically organized: All those working in Egypt, both Egyptians and Egypt's expatriate workforce, were compensated for this property transfer, which compares very favorably to the historic example of late 19th and early 20th century USA, when loosely integrated contractors had their production capital transferred into the hierarchical entity "firm" (Wagner-Tsukamoto, 2003: pp. 168-177, 185-186; 2007; 2008b).

Also, the concept of private property regarding fruits from production (crop yields) was upheld in the story of Joseph after the transfer of production capital to the state had occurred. As a result, all parties involved in economic exchange seemed to prosper, realizing mutual gains and high economic performance for the Egyptian state and its workforce, which included Egyptian workers and expatriate workers (amongst others, the Israelites). Slavery was no issue here (Wagner-Tsukamoto, 2009a). From the perspective of North and Thomas (1973), the state was in this respect strong enough to guarantee property rights but did not exploit property rights, e.g. through over-taxation or slavery. Both "private predation" and "public predation" regarding property rights were under control when Joseph reigned. This interpretation is contrary to the confiscation and slavery theses which are frequently associated with the story of Joseph, even by Weber (1952: p. 50).

Weber's fourth criterion referred to the spirit of capitalism, in particular, a godly inspired devotion to making money. More so than in the story of Jacob, this is clearly apparent in the Joseph story, wherein God revealed through dreams how Joseph could buffer industrial Egypt against downturns in the economic cycle. God here provided inspirational spiritual human capital to Joseph and then left it to Joseph's entrepreneurial skills to implement this economic policy. A devotion to making money is also reflected by Joseph's career path when he quickly progressed from the very bottom of Egypt's hierarchies to the top. Joseph showed admirable economic wits and skills which fostered the wealth not only of Egypt's elite but also of those who worked at lower levels in Egypt's industrial hierarchies. The economic ideal of mutual gains as interaction outcome, which is of such a high importance in institutional and constitutional economic analysis and the moral justification of economic activity and "capitalism" (Buchanan, 1975; Williamson, 1985), is more than apparent (Wagner-Tsukamoto, 2009a). Indeed, Joseph was the "fruitful vine" of Israel (Genesis, 49: verse 22), as the dying Jacob praised Joseph. He saved the Israelites from starvation in their homeland by bringing them to Egypt and by ensuring that they prospered alongside the Egyptians.

The identification of a true spirit for making money within the story of Joseph is further supported when examining the Huguenot criteria. Regarding criterion (1), God showed Joseph the "path to profit", through the godly inspired dreams on how to buffer Egypt against economic reversals; and Joseph traded profit making to "God's glory", especially when he saved God's people the Israelites, from starvation in their homeland. As noted, the dying Jacob had clearly realized this.

Regarding the Huguenot criterion (2), God indirectly blessed Joseph by supporting his advance to the top of Egypt's industrial hierarchies; Joseph was clearly elevated in this respect by God. And this was followed by an increase in his profit and possessions; for instance, he received jewelry, a mansion, a chariot, a wife of high social standing, the best land and other riches (Genesis, 41: verses 41-51, 47: verse 6). But as previously noted, mutual gains were ensured too, not only Joseph benefited but also those who were at lower levels of Egypt's hierarchies.

Regarding criterion (3), Joseph could measure his worth before God since he saved the Israelites and also he resisted immoral behavior, such as the seduction attempt of Potiphar's wife. Theological interpreters have even suggested that Joseph's rise to power came as a godly reward for this virtue (Kugel, 1997: p. 252). Also, Joseph's economic success was achieved by legal means from the outset, which is in complete 
contrast to the story of Jacob, where only in its final outcome can "legality" be diagnosed.

Criterion (4) relates to a special, godly purpose for selecting Joseph for economic advancement. Such a purpose is apparent with respect to the achievements of Joseph's economic policies, especially the saving of the Israelites from starvation. It is also apparent regarding the mutual prosperity he generated for both Egypt and Israel and the multicultural, pluralistic social environment that emerged as a result of Joseph's policies. God also had clearly endowed Joseph with the means to achieve godly purposes, enabling him to receive God's word through the aforementioned dreams.

To summarize, whereas for the story of Jacob I could establish the emergence of modern capitalism, especially when looking at its final outcomes, for the story of Joseph, modern capitalism in the way Weber understood it is seemingly in full bloom from the very outset. Looking at the storyline of the Hebrew Bible and here in particular the book of Genesis and the way the story of Jacob was sequenced before the story of Joseph, a larger, economic logic manifests itself with respect to the emergence of modern capitalism (in Weber's reading) but also with respect to the economic constitutionalism and institutionalism that is here visible in the Hebrew Bible.

\section{Discussion of a Textual Analysis of the Hebrew Bible and Its Projection to Actual, Historical Development}

On the grounds of the previous textual analysis of the Hebrew Bible, the Weber thesis can already be questioned. The paper has identified ideas of modern capitalism the way Weber understood it for the oldest, earliest, pre-exodus parts of the Hebrew Bible-the Genesis stories that involved Jacob and Joseph. This adds new impetus to Sombart's critique of Weber, which Sombart had largely based on the Talmud (Sombart, 1913: chap. 11). In general, an institutional economic reconstruction of the oldest and best-known books of the Hebrew Bible up to the book of Kings (Wagner-Tsukamoto, 2009a) can add new relevance and substance to Sombart's critique. Both the story of Jacob and the story of Joseph here reveal a deeply capitalist ethos when examined using Weber's criteria (including the Huguenot criteria). This fundamentally points to a critique of Weber's thesis that capitalism prior to Protestantism lacked the "spirit of capitalism" (Weber, 2001: p. 17).

As a key feature of modern capitalism, both Sombart and Weber agreed that the spirit of capitalism is increasingly rationalized (Parsons, 1928-1929: pp. 650-651, 42-43; Sombart, 1913: pp. 206-207, 226, 234). I identified such a rational but still quasi-religious spirit of capitalism in the story of Jacob and the story of Joseph and I did so in line with Weber's criteria for demarcating the spirit of capitalism. Weber went on to assert that "capitalistic adventurers" (entrepreneurs, we may call them today) which reflected the spirit of capitalism existed at all times, but stated that this was not the case for modern capitalists which reflected "the pursuit of renewed profit by means of continuous, rational, capitalistic enterprise” (Weber, 2001: p. 17; see also Giddens, 1976: p. 3). Weber argued that "adventurer capitalists" were “... opposed to the systematic and rational spirit of modern capitalism” (Parsons, 1928-1929: p. 36). Sombart, on the other hand, included such entrepreneurs in his analysis of the coming of modern capitalism.

Two comments can be made here. For one thing, an eco- nomic reconstruction (possibly not of the story of Jacob) but at least of the story of Joseph lives up to Weber's claim to "continuous, rationally conducted capitalist enterprise”. But for another thing do we have to accept Weber's suggestion that "capitalist adventurers" who did not exhibit all four of Weber's criteria of modern capitalists should be excluded from "modern capitalism"? Even today, such entrepreneurs are numerous. Without them, any economy in basically any country around the world would collapse. They are an integral input to and foundation of capitalism. Indeed, such entrepreneurs are mostly small firms, which often pioneer goods and which make up the bulk of firms in any contemporary economy around the globe (Carr, 2003: p. 8). If we question Weber in this way, the story of Jacob can also be read as a parable on modern capitalism, maybe not one reflecting the large modern firm (or "bureaucracy" as Weber may call it) but at least the small firm.

A critical question now is whether we can extend and project textual analysis of the Hebrew Bible to actual, historical analysis. This latter type of analysis is the main route through which scholars in the field of Weber studies have tried to confirm or reject the Weber thesis. Specifically with respect to Judaism, Weber claimed that both older Judaism and medieval/modern Judaism were far removed from Protestantism, the former being naïve and the latter being close to adventure capitalism and "pariah-capitalism” (Weber, 2001: p. 111). Sombart had already questioned the assertion that both ancient and modern capitalism were devoid of capitalist spirit, e.g. Sombart (1915: p. 233): "In every course of conduct the Jew asked himself whether it would tend to the glory of God". This interpretation is close to Weber's idea of the calling.

A key difference between Weber and Sombart relates to their fundamental disagreement regarding the historic emergence of a modern spirit of capitalism, Weber arguing for Protestantism in 17th and 18th century Europe, Sombart for Judaism. On the one hand, Weber's thesis can be discounted if historic evidence of "modern" Jewish capitalists can be found for 17th, 18th and 19th century Europe when modern capitalism emerged. On the other hand, Weber's thesis could even be much more strongly discounted if modern Jewish capitalists could be found predating 17th century Europe (the latter may already be implied, at least to some degree, by the above textual analysis of the Hebrew Bible).

In the following, I indicate that Jewish entrepreneurs and even "modern" Jewish capitalists existed since ancient times. However, it is beyond the scope and purpose of this paper to comprehensively review historic evidence on the economic success of Jewish businesses. Still, I want to relate selected historic evidence to the very idea of "being Jewish" in a religious or cultural sense and that this is embodied in the text "Hebrew Bible".

Throughout the centuries, as far back as many centuries before Christ, Jewish involvement in the economy seems to have been rewarded with special success. Block (2004: p. 306, 318) identifies this in general terms. More specifically, for 17th century England, Pollins (1982: pp. 35-36) confirmed that Jews were re-admitted into the country in order to foster economic development. Sombart $(1911,1913)$ himself provided an early, detailed historic account of Jewish involvement in the economy in Europe, America and Asia since the outgoing Middle Age that challenged the Weber thesis.

Also, research in economic history seems to unequivocally agree that throughout time and basically in any country in 
which Jewish businesses were active they rapidly achieved a prominent if not dominating role in the economy, despite being only a small minority (a "pariah community" in Weber's terms). Even one of Weber's (2001: p. 133) own examples seems to underline this point for German Jews. Exemplary also is a statement by Beller (1995: p. 715), reviewing Silber (1992): "Jews, never more than 5 per cent of the population, ... achieved ... a spectacular-not to say dominant—position in the Hungarian economy”. Especially interesting in this regard is Don (1992) who suggested that the success of Jewish businesses was due to learned experience and their cultural traditions. As Don (1992) and Beller (1995) agree, "Jewishness" seems to play in this respect an independent role in making Jewish businesses successful in the modern Hungarian economy; or as Ashtor (1984: p. 234) put it, "faithfulness to the ancestral religion" explains the-successful-economic role of Jews.

Once such an independent role is attributed to the variable "Jewishness", it can be economically reconstructed. I did this in this paper when reviewing the stories of Jacob and the stories of Joseph through economic concepts and by linking this review to the Weber criteria. This link between Jewishness as a learned, religious and cultural experience, its economic reconstruction in relation to the Hebrew Bible (here: also in relation to Weber's criteria on modern capitalism), and the actual success of the Jewish business in the economy is all I need to fundamentally question the Weber thesis. As a by-product, I would reject any attempt to explain Jewishness and its relationship to successful Jewish business in a biological, "innate" manner, as Sombart attempted, or some essays by Silber (1992).

Similarly as for Hungary, Mosse (1987: p. 383, 386, 393-395) attributed the extraordinary success of German Jews in the banking sector, in trade and in industries such as textiles, the heavy industries and the electrical industry in the 19th and early 20th century to their history, culture, minority status and ethnicity, which I interpret as evidence, at least in parts, of their religion and culture and especially the economic fabric of their religion. This view is further endorsed since Mosse (1987: p. 405 ) in his final analysis explicitly draws on Sombart to underline the important role Jews played in German economic development. Brenner (1997: p. 302) also talked about a special enterprising mentality of Jews in this connection. Brenner (1997: pp. 301-308) made another very significant point: He confirmed that German Jews in the 19th century achieved a rapid rise in various industries once Germany liberalized, deregulated and institutionally lowered barriers that previously had prohibited Jews from entering certain industries.

Barbalet (2006: pp. 57-59) had analyzed this institutional influence on German Jews as far back as in the 11th and 12th century, as did Ashtor (1983: chap. II/149-150, chap. VIII/ 8586) with his review of comparable barriers for the Mediterranean economy from the 10th century onwards (see also Baron 1975b: p. 39; 1975c: p. 58). Fuks-Mansfeld (2002a: pp. 173174) looked at such institutional barriers for 18th century Netherlands, which prevented Jews from entering certain economic activities, and Fuks-Mansfeld (2002b: p. 213) noted that Jews became "pioneers in mechanization" of cotton mills by the mid-1850s (once institutional barriers were removed). Blom and Cahen (2002: p. 241) found for the Netherlands that in the following decades (after the 1850s) Jews spread to all occupations from which they previously had been excluded. Fishman (1989: p. 287) similarly commented that Jews managed to re- linquish their status of "pariah capitalism", to which Weber tried to restrain them, once institutional barriers came down so dramatically in the 19th century. Hanak (1992: p. 36) looked at such barriers for 19th century Hungary as did Kahan (1986: p. 2, 34-35, 38) for 19th century Russia.

As a result of institutional liberalization and deregulation in 18th and 19th century Europe, Jews gained fuller access to the economic system and this enabled them to "emancipate" the economic system (see also Bloom, 1959: pp. 112-121; Kahan, 1986: p. 87, 90, 97; Hanak, 1992: pp. 26-27, 33, 38; FuksMansfeld, 2002a: pp. 178-179). As a consequence, they participated in the re-birth of modern capitalism in Europe (at least from the mid-19th century onwards) - "re"-birth as compared to biblical examples, especially the story of Joseph, but also "real world" examples, such as the sugar refinery example of Ashtor for 13th and 14th century Egypt (see below).

The real significance of institutional, commercial-legal barriers seems to have been overlooked by Weber (1965: pp. 248-250) when he argued that Jews refrained from building up factory-like, industrial organizations as ascetic Protestants had done. Weber (1924: p. 307) was certainly aware that institutional barriers for 16th and 17th century Germany prevented Jews from becoming modern capitalists, but such awareness did not prompt him to more critically examine his thesis on the birth of capitalism. The implication of acknowledging institutional barriers is that once they were removed it enabled Jews to quickly take on the role of "modern" capitalists. Key examples were listed in this respect above.

It is one thing to say that Jews lacked a capitalist spirit and quite another that it was institutional barriers that prevented them from exercising and expressing this spirit-as they did indeed do once preventive institutional barriers came down, and as they had done before the industrial revolution of modern times (as long as institutional barriers had not been in place). The latter is substantiated by various historic examples: Prior to the 17th century, Ashtor (1983) confirmed that Jews occupied very prominent economic positions in many countries around the Mediterranean economies, especially when no discriminatory occupational barriers were erected against them; for instance, Jews were heavily involved in the tanning and dyeing industries of Egypt, Syria and Babylonia around the 10th century (Baron, 1975a: p. 32), in the silk industry of Italy in the 12th century (Baron, 1975b: p. 38), in the sugar refining industry of Egypt in the 13th and 14th centuries (Ashtor, 1983: chap. VIII/85-86; see also Pohl, 1975: pp. 189-190), in the mining and armament industries of Central and Eastern Europe in the 16th and 17th centuries (Baron, 1975c: pp. 62-64, 71), and in the mining industries of a number of countries in the 18th and 19th centuries (Kaplan, 1975: pp. 174-177).

These examples serve to directly contest Weber's (1924: pp. 306-307) claim that the Jews played no part in the birth of modern capitalism, especially its rational, industrial set-up. Another example comes from Johanek (1999: pp. 70-71, 81-82) who found that Jews were "long-distance traders par excellence”, dominating, despite being only a small minority, the trade routes between Europe and the Islamic world in the 10th and 11th century (see also Baron, 1975a: pp. 28-29). Such trading empires were at least to some degree, supported by institutional measures, e.g. the granting of royal trade charters and other privileges to Jews. This again hints at the importance of institutional influences for understanding the birth of capitalism. 
Some of Weber's other claims can be discounted in relation to the above examples, too, especially the Hungarian one. In Hungary, and contrary to Weber's expectations (1924, p. 307), Jews successfully organized other Jews into industrial organizations in the 19th century (Hanak, 1992: pp. 27-28), and these Hungarian Jews were highly successful in innovating and branching out into new industries (Hanak, 1992: pp. 32-33, 36, 39). With regard to the latter industries Jews clearly did not show a traditionalistic shyness which made them averse to innovation, which Weber (1924: p. 307) claimed existed in Judaism and its grounding in the Talmud. Also, even in Poland, and in direct opposition to Weber's claims, Jewish industrialists had employed in certain sectors predominantly Jewish workers in their factories (Baron, 1975d: p. 88).

This short review has to suffice at this point to indicate that historically Jews have been highly successful as capitalist businesses and that their behavior is likely to live up in virtually every way to being "modern” in Weber's own reading. It has also become apparent that Jewish economic success throughout time seemed not to be related to special periods of time or to special countries. This absence of any specific causative relationships gives rise to the question as to how could the prominent success of Jewish capitalists be explained: The institutional/constitutional (de-)regulation of their economic activities was an important intervening variable. This is contrary to mono-causal explanations which Weber generally favored regarding the emergence of modern capitalism and religious belief (Barbalet, 2006: p. 55).

As already noted, I do not want to enter any race-related biological analysis but rather a cultural pedagogic one that focuses on the central religious embodiment of Judaism, the text "Hebrew Bible" - and its economic, capitalist fabric and ethos. Sombart (1913: p. 274) seemingly implied this when referring to the "parallelism between the Jewish character, the Jewish religion and capitalism”. (See also Sombart, 1915: p. 233, 265) Judaism, as embodied in the Hebrew Bible, thus functions as an independent variable to explain the success of the Jewish business. The key thesis here is that by being culturally exposed to the Hebrew Bible from earliest childhood and throughout life, Jews received an excellent schooling not only in religious behavior and cultural traditions but also in economic behavior. As noted, Sombart (1913: p. 193), and Marx (1967) too, had hinted at this early on.

\section{Conclusion}

In the first part of this paper, I analyzed the story of Jacob and the story of Joseph on textual grounds. I developed the thesis that Weber's criteria for setting out modern capitalism and here especially the spirit of capitalism can be identified through institutional economic reconstruction for these stories. An ancient text like the Hebrew Bible, and here particularly the pre-exodus book of Genesis, already clearly reflects what Weber later unearthed through actual historical analysis as being a particularly modern, capitalist phenomenon. My analysis could easily be extended to other stories of the Hebrew Bible, e.g. the paradise story (Wagner-Tsukamoto, 2009a, 2009b, forthcoming), which in many ways compares well to the story of Jacob, or the Solomon story and the bureaucratic, institutional structures it portrays, which can be linked to institutional economics, e.g. Williamson (1985) or North and Weingast (1989). Future research could address these topics. The pre-exodus focus of my economic reconstruction particularly questions one of Weber's central claims, namely that ascetic Protestantism was inspired not by “... Judaism at the time of the writing of the Scriptures, but by Judaism as it became under the [post-exilic] influence of many centuries of formalistic, legalistic, and Talmudic education. [However] even then ... the general tendency of the older Judaism toward a naïve acceptance of life as such was far removed from the special characteristics of Puritanism" (Weber, 1976: p. 165; see also Barbalet, 2006: p. 52).

Contrary to Weber, my economic reconstruction of the story of Jacob and the story of Joseph demonstrated that the "older" type of Judaism, which was supposedly "naïve” in Weber's reading, already exhibited the key features of modern capitalism (as Weber conceptualized them).

Weber also claimed that only ascetic Protestantism helped to cultivate and promulgate modern capitalism in the 17th and 18th centuries in the western world. I can revise and extend this thesis to religions in general that are grounded in the Hebrew Bible, and here especially Judaism and the economic success and high economic performance Jewish businesses enjoyed throughout time. Unfortunately, one simple type of historical economic analysis related to the economic performance of a country or state throughout time is not possible since Jewish businesses have been dispersed across many countries. In this respect, a micro focus on Jewish business communities within a country appears advisable. Such studies exist at least to some extent, and they underline that the purely textual revision of the Weber thesis I suggested above in relation to the Hebrew Bible (and in relation to "older" Judaism) can also be projected in actual, historic perspective, to highlight both medieval and modern Judaism. Weber claimed regarding medieval and modern Judaism that it reflected only "adventure capitalism” which was grounded in the "ethos ... of pariah capitalism. Puritanism carried the ethos of rational organization of capital and labor. It took over from the Jewish ethic only what was adapted to this purpose” (Weber, 1976: pp. 165-166; see also Barbalet, 2006: p. 53) As noted, Weber did not acknowledge the real significance of institutional barriers as he chose to overlook historic - both medieval and modern-examples of Jewish participation in the (re-)birth of modern capitalism and its rational, industrial setup.

Thus, the key theses developed in the present paper are twofold: First, I suggested that an ancient text like the Hebrew Bible, and here already the pre-exodus Scriptures, reflect what Weber called a capitalist ethos, even a capitalist ethics. And second, I argued that the economic message that emerged from the Hebrew Bible had a deep, this-worldly, behavioral, pedagogic impact on those for whom the Hebrew Bible provided moral and cultural guidance (once institutional, commerciallegal barriers were removed). Both theses challenge Weber's thesis. I formulated as counter-thesis to Weber the suggestion that an ancient religion like Judaism, as embodied in the Hebrew Bible, was already grounded in a deeply capitalist, economic ethics for the purpose of resolving worldly problems of private contracting and societal contracting in comparatively rational, secular and modern terms.

An institutional economic reconstruction of the Hebrew Bible implies that religious ethics in itself is fundamentally based on capitalist ideas, even a capitalist ethics (reflecting economic institutions, e.g. property rights; capital exchange; mutual gains as interaction outcome; the model of economic man, and an economic conflict model, the latter were not fully explored in 
this paper; see Wagner-Tsukamoto, 2009a, 2009b, 2010). Judaism can in this respect be characterized as inherently "modern", "secular" and "rational" (at least more so than traditional Christian belief, e.g. Catholicism) because of its affinity to economic thought.

From here it is only a small step to suggest the more general thesis that a modern religion is grounded in economic ethics and that this accounts for the economic success of Jewish businesses as far back as many centuries before Christ—but also of Protestant religions, as Weber unearthed for 17th and 18th century Europe. Weber's thesis is in this respect only a special case of this more general thesis. This thesis accommodates Weber's suggestions on the role of Protestantism in economic development in 17th and 18th century Europe but also of Judaism as far back as in ancient times, both reflecting "modern", economized religions.

On the other hand, the thesis also suggests the analysis of whether the economic underperformance of certain traditionalist and comparatively "non-economic", "non-modern" theologies, especially in contemporary society, for instance Confucianism or Quakerism (Cheung \& King, 2004; Childs, 1964; Wagner-Tsukamoto, 2008c), can be related to their lacking affinity to economic ethos and capitalist ethics. More generally, it has to be examined in this regard what role, if any, religion plays in contemporary societies of the 21st century, especially so in morally inspiring businesses and their scope for economic success.

As noted, this thesis that modern religion is grounded in economic ethics (in the sense I outlined it above) can to some extent explain the economic success of Jewish businesses but also of Protestant ones the way Weber identified it for 17th and 18th century Europe. For Jewish businesses, I explained that their religious belief system, as embodied by the Hebrew Bible, was deeply grounded in "modern" capitalist ideas. WagnerTsukamoto (2009a) advanced this argument in general terms for Judaism through institutional and constitutional economic reconstruction, which is different from and goes much further than Marx's (1967) or Sombart's $(1911,1913)$ attempts to attribute certain economic (character) traits, such as self-interest, to Judaism (see also Fishman, 1989: pp. 282-283). I fundamentally disagree in this respect with Weber who claimed that Judaism remained traditionalistic and pre-modern and anchored in "pariah capitalism" (critically also discounted by Barbalet, 2006: p. 56; see also above). Sombart similarly stated in this connection, as Parsons (1928-1929: p. 649) reviewed, that a peculiar capitalist spirit helped the evolution of modern "new" religion. Sombart followed this up for Judaism in modern times (but otherwise he specifically questioned this for Protestantism, and in this respect I disagree with Sombart; e.g. Sombart, 1915: pp. 251-253, 261-262).

For Protestant businesses, I suggested a similar economizing — “modernization", "secularization” and "rationalization"—of Christian belief in the wake of Reformation movements. I proposed that Protestant and Calvinist movements led to an infiltration of economic ideas into the New Testament-based Christian belief system, in particular in comparison to the non-reformed Churches and especially Catholicism (as Weber stressed; see Parsons, 1928-1929: p. 42). This analysis can be extended to the historical analysis of the economic performance of those countries in which the Reformation and an apparent "economizing" of religious thought took place in 17th and 18th century Europe (North and Weingast (1989) could be projected in this perspective).

This thesis on the economizing of Christianity in the wake of the Reformation can even be linked to Judaism, as hinted at by Sombart: The Reformation seemed to bring the reformed Churches closer to the rational economic character of Judaism, at least so in generic perspective. Mosse (1987: p. 29), for instance, talked of a rationalistic, "Puritan ethic" of Judaism. Regarding the Weber thesis, I therefore feel justified in deepening my criticism by showing that "modern" Protestants drew on the text "Hebrew Bible". I argue that a Reformist leaning on the Hebrew Bible caused a rationalization, secularization and modernization-“economizing”—of traditional Christian belief and subsequently contributed, inspired by Judaism, to the rebirth of modern capitalism along Protestant lines. This happened to a far greater degree than envisaged by Weber.

Textually, I confirmed this point through re-interpreting the Genesis stories involving Joseph and Jacob. Historically, Pollins (1982: pp. 29-30) hinted at this for 17th century England, although without referring to Weber. Sombart (1913: p. 222) implied this, too, when stating: "Religion of the [traditional, non-Protestant] Christians stood in the way of their economic activities ... Jews were never faced with this hindrance” (also Sombart, 1913: p. 244). Sombart (1913: pp. 249-251) even went on to suggest that the "Puritans", such as Calvinists, achieved a "rationalization" and increasing economic aptitude of their religion by stronger drawing on the Hebrew Bible-as compared with traditional Christians who remained much more focused on the New Testament and its comparatively mystic, other-worldly interpretation (also hinted at by Sombart, 1913: p. 226; 1915: pp. 264-265; see also Fishman, 1989: pp. 285-286; Lehmann, 2005: p. 22).

To a certain degree Weber appeared to agree with Sombart on this point but then argued that the "pariah status" of the Jews had prevented them from relating to the external world and with that the involvement and generation of modern capitalism as an economic system (Fishman, 1989: pp. 286-287; Weber, 1968: pp. 615-623). However, as indicated above, this "pariah status" was largely externally imposed on the Jews through various institutional barriers - and these barriers dramatically crumbled away in 18th and 19th century Europe (and they did not always exist in earlier periods in other countries where Jewish involvement in the economy then blossomed). Once existing institutional barriers collapsed Jewish businesses could more fully participate in the re-birth of modern capitalism on their own (in addition to "inspiring" the Reformation movements, at least much more so than Weber thought).

Questions of effective state formation arise as a result of the present paper. Gorski (2005: pp. 184-185) discussed in this respect patrimonial absolutism for Catholic Europe in the 17th and 18th century, and suggested that this type of state structure undermined economic performance whereas countries with strong Reformist movements enjoyed a much higher economic performance because of the constitutional structures they set up -in largely economic terms, I would add here (see also North \& Weingast, 1989). As I suggested above, I would link these suggestions made by Gorski to the economic purification and economic strengthening of religious belief in the wake of Reformation movements, which at least saw a secularization, modernization and rationalization of religion in comparison to traditional Christian belief, such as Catholicism. This leads to the broader thesis that high economic performance of both businesses and states was supported by "modern", "rational", 
"secular" religion: That is grounded in an economic, capitalist ethics, as so well embodied by Judaism or ascetic Protestantism.

\section{REFERENCES}

Armstrong, K. (1996). In the beginning. A new reading of the book of genesis. London: Harper-Collins.

Ashtor, E. (1983). The Jews and the Mediterranean economy, 10th-15th Centuries. London: Variorum.

Axelrod, R. (1984). The evolution of cooperation. New York: Basic Books.

Barbalet, J. (2006). Max Weber and Judaism: An insight into the methodology of The Protestant Ethic and the Spirit of Capitalism. Max Weber Studies, 6, 51-67.

Baron, Salo W. (1975a). The Muslim Middle Ages. In N. Gross (Ed.), Economic history of the Jews (pp. 25-34). Jerusalem: Keter Publishing House Jerusalem.

Baron, Salo W. (1975b). Medieval Christendom. In N. Gross (Ed.), Economic History of the Jews (pp. 35-47). Jerusalem: Keter Publishing House Jerusalem.

Baron, Salo W. (1975c). The early modern period. In N. Gross (Ed.), Economic history of the Jews (pp. 55-78). Jerusalem: Keter Publishing House Jerusalem.

Baron, Salo W. (1975d). The modern period. In N. Gross (Ed.), Economic history of the Jews (pp. 83-104). Jerusalem: Keter Publishing House Jerusalem.

Beller, S. (1995). Review of Jews in the Hungarian economy, 17601945. Journal of Interdisciplinary History, 25, 715-716. doi: $10.2307 / 205824$

Block, W. (2004) The Jews and capitalism: A love-hate enigma. The Journal of Social, Political, and Economic Studies, 29, 305-326.

Blom, J. C., \& Cahen, J. J. (2002). Jewish Netherlanders, Netherlands Jews, and Jews in the Netherlands, 1870-1914. In J. C. Blom, R. G. Fuks-Mansfeld, \& I. Schoeffer (Eds.), The history of the Jews in the Netherlands (pp. 230-295). Oxford: Littman Library.

Bloom, H. I. (1959). Felix libertate and the Emancipation of Dutch Jewry. In J. L. Blau (Ed.), Essays on Jewish life and thought (pp. 105-122). New York: Columbia University Press.

Brenner, M. A. (1997). Economic ascent. In M. A. Meyer (Ed.), German-Jewish history in modern times, Vol. 2 (pp. 301-308). New York: Columbia University Press.

Buchanan, J. M. (1975). The limits of liberty. Between Anarchy and Leviathan. Chicago: University of Chicago Press.

Carr, P. (2003). Revisiting the protestant ethic and the spirit of capitalism: Understanding the relationship between Ethics and Enterprise. Journal of Business Ethics, 47, 7-16. doi:10.1023/A:1026232726129

Cheung, T. S., \& King, Y. A. (2004). Righteousness and profitableness: The moral choices of contemporary Confucian entrepreneurs. Journal of Business Ethics, 54, 245-260. doi:10.1007/s10551-004-6405-6

Child, J. (1964). Quaker employers and industrial relations. Sociological Review, 12, 293-313. doi:10.1111/j.1467-954X.1964.tb01260.x

Davidson, R. (1979). Genesis 12-50. Cambridge: Cambridge University Press.

Don, Y. (1992). Patterns of Jewish economic behaviour in central Europe in the 20th century. In M. K. Silber (Ed.), Jews in the Hungarian Economy, 1760-1945 (pp. 247-273). Jerusalem: Magnes Press/Hebrew University.

Fishman, A. (1989). The religious kibbutz: A note on the theories of Marx, Sombart, and Weber on Judaism and economic success. Sociological Analysis, 50, 281-290.

Fuks-Mansfeld, R. G. (2002a). Enlightenment and emancipation, from c.1750 to 1814. In J. C. Blom, G. R. Fuks-Mansfeld, \& I. Schoeffer (Eds.), The history of the Jews in the Netherlands (pp. 164-191). Oxford: Littman Library.

Fuks-Mansfeld, R. G. (2002b). Arduous adaptation, 1814-1870. In J. C.
Blom, R. G. Fuks-Mansfeld, \& I. Schoeffer (Eds.), The history of the Jews in the Netherlands (pp. 192-229). Oxford: Littman Library.

Giddens, A. (1976). Introduction. In M. Weber (Ed.), The Protestant Ethic and the Spirit of Capitalism (pp. 1-17). London: Allen and Unwin.

Gordon, B. (1989). The economic problem in biblical and patristic thought. Leiden, New York: Brill.

Gorski, P. S. (2005). The little divergence. The protestant reformation and economic hegemony in early modern Europe. In W. H. Swatos, \& L. Kaelber (Eds.), The Protestant Ethic turns 100. Essays on the centenary of the Weber Thesis (pp. 165-190). London: Paradigm Publishers.

Graves, R., \& Patai, R. (1964). Hebrew myths. The book of genesis. London: Cassell.

Grundmann, R., \& Stehr, N. (2001). Why is Werner Sombart not part of the core of classical sociology?: From fame to (near) oblivion. Journal of Classical Sociology, 1, 257-287. doi:10.1177/14687950122232558

Hanak, P. (1992). Jews and the modernization of commerce in Hungary, 1760-1848. In M. K. Silber (Ed.), Jews in the Hungarian economy, 1760-1945 (pp. 23-39). Jerusalem: Magnes Press/Hebrew University.

Johanek, P. (1999). Merchants, markets and towns. In T. Reuter (Ed.), The new Cambridge medieval history, Vol. III, c.900-c.1024 (pp. 64-94). Cambridge: Cambridge University Press.

Kaelber, L. (2005). Rational capitalism, traditionalism, and adventure capitalism. New research on the Weber Thesis. In W. H. Swatos, \& L. Kaelber (Eds.), The protestant ethic turns 100. Essays on the centenary of the Weber Thesis (pp. 139-163). London: Paradigm Publishers.

Kahan, A. (1986). Essays in Jewish social and economic history. Chicago: University of Chicago Press.

Kaplan, L. (1975). Metals and mining. In N. Gross (Ed.), Economic history of the Jews (pp. 173-178). Jerusalem: Keter Publishing House Jerusalem.

Kugel, J. L. (1997). The Bible as it was. London: Belknap/Harvard University Press.

Landheer, B. (1951). Review of Werner Sombart's the Jews and Modern Capitalism. American Sociological Review, 16, 587-588.

Lehmann, H. (1993). The rise of capitalism: Weber versus Sombart. In H. Lehmann, \& G. Roth (Eds.), Weber's protestant ethic: Origins, evidence, contexts (pp. 195-208). Cambridge: Cambridge University Press.

Lehmann, H. (2005). Friends and foes. The formation and the consolidation of the protestant ethic thesis. In W. H. Swatos, \& L. Kaelber (Eds.), The protestant ethic turns 100. Essays on the centenary of the Weber Thesis (pp. 1-22). London: Paradigm Publishers.

MacKinnon, M. H. (1993). The longevity of the thesis: A critique of the critics. In H. Lehmann, \& G. Roth (Eds.), Weber's protestant ethic: Origins, evidence, contexts (pp. 211-243). Cambridge: Cambridge University Press.

Marx, K. (1967). On the Jewish question. In K. Marx (Ed.), The writings of young Marx on philosophy and society (pp. 216-248). Garden City: Doubleday.

Mosse, W. E. (1987). Jews in the German economy. The GermanJewish elite 1820-1935. Oxford: Clarendon Press.

Nipperdey, T. (1993). Max Weber, Protestantism, and the debate around 1900. In H. Lehmann, \& G. Roth (Eds.), Weber's protestant ethic: Origins, evidence, contexts (pp. 73-81). Cambridge: Cambridge University Press.

North, D. C., \& Thomas, R. P. (1973). The rise of the western world. A new economic history. Cambridge: Cambridge University Press.

North, D. C., \& Weingast, B. R. (1989). Constitutions and commitment: The evolution of institutions governing public choice in seventeenthcentury England. The Journal of Economic History, 49, 803-832. doi:10.1017/S0022050700009451

Parsons, T. (1928-1929). "Capitalism” in recent German literature: Sombart and Weber. Journal of Political Economy, 36-37, 641-661. doi:10.1086/253984

Plaut, W. G. (1981). The Torah. A modern commentary. New York: Union of American Hebrew Congregation. 


\section{S. WAGNER-TSUKAMOTO}

Pohl, H. (1975). Sugar trade and industry. In N. Gross (Ed.), Economic history of the Jews (pp. 189-190). Jerusalem: Keter Publishing House Jerusalem.

Pollins, H. (1982). Economic history of the Jews in England. London: Associated University Press.

Rad von, G. (1963). Genesis. A commentary. London: SCM Press.

Schmidt, W. H. (1984). Introduction to the Old Testament. London: SCM Press.

Silber, M. K. (1992). Jews in the Hungarian economy, 1760-1945. Jerusalem: Magnes Press/Hebrew University.

Sombart, W. (1902). Der moderne Kapitalismus. Ester band: Die genesis des Kapitalismus. Leipzig: Duncker and Humblot.

Sombart, W. (1911). Die Juden und das Wirtschaftsleben. Leipzig: Duncker and Humblot.

Sombart, W. (1913). The Jews and modern capitalism. New York: Burt Franklin.

Sombart, W. (1915). The quintessence of capitalism: A study of the history and psychology of the modern businessman. London: T. F. Unwin.

Sombart, W. (1922). Der moderne Kapitalismus: Historisch-systematische Darstellung des gesamteuropäischen Wirtschaftsleben von seinen Anfängen bis zur Gegenwart. München, Leipzig: Duncker and Humblot.

Swatos, W. H., \& Kivisto, P. (2005). The contexts of the publication and reception of the protestant ethic. In W. H. Swatos, \& Kaelber, L. (Eds.), The protestant ethic turns 100. Essays on the centenary of the Weber Thesis (pp. 111-137). London: Paradigm Publishers.

Wagner-Tsukamoto, S. A. (2001). Economics of genesis. On the institutional economic deciphering and reconstruction of the legends of genesis. Journal of Interdisciplinary Economics, 12, 249-287.

Wagner-Tsukamoto, S. A. (2003). Human nature and organization theory. On the economic approach to institutional organization. Cheltenham, New York: Edward Elgar.

Wagner-Tsukamoto, S. A. (2005). An economic approach to business ethics: Moral agency of the firm and the enabling and constraining effects of economic institutions and interactions in a market economy. Journal of Business Ethics, 60, 75-89. doi:10.1007/s10551-005-5842-1

Wagner-Tsukamoto, S. A. (2007). An institutional economic reconstruction of scientific management: On the lost theoretical logic of Taylorism. Academy of Management Review, 32, 105-117. doi:10.5465/AMR.2007.23463879

Wagner-Tsukamoto, S. A. (2008a). An economic reading of the Exodus:
On the institutional economic reconstruction of biblical cooperation failures. Scandinavian Journal of the Old Testament, 22, 114-134. doi:10.1080/09018320802185150

Wagner-Tsukamoto, S. A. (2008b). Scientific management revisited: Did Taylorism fail because of a too positive image of human nature? Journal of Management History, 14, 348-372. doi:10.1108/17511340810893108

Wagner-Tsukamoto, S. A. (2008c). Contrasting the behavioural business ethics approach and the institutional economic approach to business ethics: Insights from the study of Quaker employers. Journal of Business Ethics, 82, 835-850. doi:10.1007/s10551-007-9596-9

Wagner-Tsukamoto, S. A. (2009a). Is God an economist? An institutional economic reconstruction of the Old Testament. Basingstoke: Palgrave Macmillan.

Wagner-Tsukamoto, S. A. (2009b). The paradise story: A constitutional economic reconstruction. Journal for the Study of the Old Testament, 34, 147-170. doi:10.1177/0309089209356416

Wagner-Tsukamoto, S. A. (2010). Out of a slave contract: The analysis of pre-Hobbesian anarchists in the Old Testament. Constitutional Political Economy, 21, 288-307. doi:10.1007/s10602-009-9084-6

Wagner-Tsukamoto, S. A. (2011). After the theft: Natural distribution states and prisoner's dilemmas in the Paradise story. Conference $\mathrm{Pa}$ per Presented at the Conference: "Religion and Capitalism, Societa, Forum for Ethics, Arts, and Law \& Religion and Transformation in Contemporary European Society”, Vienna: University of Vienna. http://hdl.handle.net/2381/9828

Wagner-Tsukamoto, S. A. (2012) The tree of life: Banned or not banned? A rational choice interpretation. Scandinavian Journal of the Old Testament (forthcoming).

Weber, M. (1924). Wirtschaftsgeschichte. Leipzig: Duncker and Humblot.

Weber, M. (1952). Ancient Judaism. London: Allen and Unwin.

Weber, M. (1965). The sociology of religion. London: Methuen.

Weber, M. (1968). Economy and society. New York: Bedminster Press.

Weber, M. (1976). The protestant ethic and the spirit of capitalism. London: Allen and Unwin.

Weber, M. (2001). The protestant ethic and the spirit of capitalism. London: Routledge.

Weber, M. (2002). The protestant ethic and the spirit of capitalism and other writings. New York: Penguin.

Westermann, C. (1986). Genesis 12-36. A commentary. London: SPCK.

Williamson, O. (1985). The economic institutions of capitalism. New York: Free Press. 